Int. J. Dev. Biol. 56: 779-787 (2012)

doi: $10.1387 / \mathrm{ijdb} .120142 \mathrm{pk}$

\title{
Regulation of germ cell meiosis in the fetal ovary
}

\author{
CASSY M. SPILLER, JOSEPHINE BOWLES and PETER KOOPMAN* \\ Institute for Molecular Bioscience, The University of Queensland, Australia
}

\begin{abstract}
Fertility depends on correct regulation of meiosis, the special form of cell division that gives rise to haploid gametes. In female mammals, germ cells enter meiosis during fetal ovarian development, while germ cells in males avoid entering meiosis until puberty. Decades of research have shown that meiotic entry, and germ cell sex determination, are not initiated intrinsically within the germ cells. Instead, meiosis is induced by signals produced by the surrounding somatic cells. More recently, retinoic acid (RA), the active derivative of vitamin $A$, has been implicated in meiotic induction during fetal $X X$ and postnatal $X Y$ germ cell development. Evidence for an intricate system of RA synthesis and degradation in the fetal ovary and testis has emerged, explaining past observations of infertility in vitamin A-deficient rodents. Here we review how meiosis is triggered in fetal ovarian germ cells, paying special attention to the role of RA in this process.
\end{abstract}

KEY WORDS: germ cell, meiosis, ovary, retinoic acid

\section{Introduction}

Mammalian life begins with the union of two cells, spermatozoa and oocytes, the generation and maturation of which are carefully controlled throughout fetal and reproductive life. In the embryo, the specification and migration of germ cells to the developing gonads is the same in males and females. When the primordial gonads begin to differentiate as ovaries or testes, the developmental pathways of germ cells diverge, leading to either oogenesis in females or spermatogenesis in males. In a newly specified ovary, germ cells enter into the first phase of meiosis - the special form of cell division, unique to germ cells, that allows them to produce haploid cells necessary for sexual reproduction. In the fetal ovary, entry into meiosis is seen as the first indication that germ cells have embarked on oogenesis (McLaren 1984). In a newly specified testis, germ cells enter a period of mitotic quiescence and remain in that state until just prior to puberty, when meiosis commences (Hilscher 1974).

Clearly, sex differentiation represents a crucial fork in the road of germ cell development and it is important to understand how the correct path is chosen. Somewhat surprisingly, the intrinsic sex chromosome content of the germ cells ( $X X$ or $X Y$ ) plays no part in this decision, but instead the germ cells are instructed by molecular signals from the testicular or ovarian environment (Evans et al., 1977; Ford et al., 1975; Palmer and Burgoyne 1991). In the last decade, the nature of some of these signals has been uncovered. In this review we focus on how meiosis entry is trig- gered in the fetal ovary and especially on the role of retinoic acid (RA) in the process.

\section{Generating germ cells: a brief history}

Germ cells originate from the primitive streak of the extra-embryonic ectoderm from 6.25 days post coitum (dpc) in the mouse embryo (Lawson 1999; Ying et al., 2000; Ying and Zhao 2001). At this time, bone morphogenetic protein (BMP) signalling factors BMP2 and BMP4 emanate from the extra-embryonic ectoderm and visceral endoderm to induce germ cell markers within a cohort of approximately 40 cells by $7.25 \mathrm{dpc}$ (Ohinata et al., 2005; Saitou et al., 2002). Accordingly, loss of BMP signalling results in a diminished founding germ cell population (Ying et al., 2000). Consistent with the pluripotent nature of the germ cell population, their transcriptional profile is characterised by expression of pluripotency genes, including Oct3/4 and Sox2 (Ohinata et al., 2005; Scholer et al., 1990; Yabuta et al., 2006), and repression of somatic marker genes under the influence of BLIMP1 (Hayashi et al., 2007; Ohinata et al., 2005). For a comprehensive review of this process, see (Saitou 2009).

Abbreviations used in this paper: CYP26, cytochrome P450-related hydroxylase; EC, embryonal carcinoma; ES, embryonic stem; HDAC, histone deacetylase; RA, Retinoic acid; RALDH, retinal dehydrogenase; RAR, retinoic acid receptor; RXR, retinoid-X receptor; SAHA, suberoylanilide hydroxamic acid; SC, synaptomemal complex; TSA, trichostatin-A; VAD, vitamin A deficient.

\footnotetext{
*Address correspondence to: Peter Koopman. Institute for Molecular Bioscience, The University of Queensland, Brisbane, QLD, 4072, Australia. Tel: +61-7-3346-2059. Fax: +61-7-3346-2101. e-mail: empkoopm@uq.edu.au - web: www.imb.uq.edu.au/groups/koopman
}

Final, author-corrected PDF published online: 5 February 2013. 
As development progresses the germ cells proliferate and migrate out of the ectoderm and into the embryo proper. Here they become motile in response to directional cues originating from the surrounding soma, including stromal derived factor 1 . This change in motility is correlated with germ cell morphological changes, such as polarisation and extension of cytoplasmic protrusions (Anderson et al., 2000). From 8.5 - 10.5 dpc the germ cells migrate anteriorly through the hindgut towards the newly forming genital ridges (Lawson and Hage 1994; Molyneaux et al., 2001); reviewed by (Richardson and Lehmann 2010). Once residing in the genital ridges, motility and polarisation are lost and the germ cells exhibit a large rounded shape with prominent nucleoli and surrounding ring-like cytosol (Baillie 1964; Donovan et al., 1986). Changes to chromatin architecture also occur upon entry into the genital ridge; germ cells erase all genome methylation (Hajkova et al., 2002; Sato et al., 2003; Szabo et al., 2002) and lose repressive histone modifications (Hajkova et al., 2008; Seki et al., 2005). The previously inactive $\mathrm{X}$ chromosome of $\mathrm{XX}$ germ cells is also re-activated (Monk and McLaren 1981; Tam et al., 1994).

\section{Cross-roads: oogenesis or spermatogenesis?}

Having reached the genital ridges, the surrounding somatic cells become responsible for nurturing the germ cell lineage during all subsequent stages of development. In addition to supporting germ cell survival, coercing the germ cells towards oogenesis or spermatogenesis is arguably the most crucial role of the soma at this time. During specification, migration and genital ridge colonisation, the behaviour of $X X$ and $X Y$ germ cells is identical; it is only when sex differentiation of the gonadal soma has occurred that germ cells commit to a male or female sexual fate (McLaren and Southee 1997). In an XY genital ridge, expression of the gene Sryfrom 10.5 dpc in pre-supporting cells triggers differentiation of Sertoli cells and the subsequent cascade of testis development (Koopman et al., 1991). Germ cells in the fetal testis environment become encased within the developing testis cords and are directed to enter the $G_{1}$ / $\mathrm{G}_{0}$ phase of mitosis from $12.5 \mathrm{dpc}$, apparently marking their commitment to spermatogenesis (Hilscher 1974). In males, germ cells initiate meiosis postnatally. In an XX genital ridge, in the absence of Sry, expression of Rspo1, Wnt4 and Foxl2 in the pre-supporting cells triggers ovarian development (reviewed by (Liu et al., 2010)). Germ cells in the fetal ovary are directed to enter the first phase of meiosis from 12.5 - $13.5 \mathrm{dpc}$, apparently marking their commitment to oogenesis (McLaren and Southee 1997).

\section{Meiosis: mechanics and markers}

Meiosis involves two rounds of cell division, the first (Meiosis I) with, and the second (Meiosis II) without, DNA replication. Sharing many similarities with mitosis, each division is broken into the stages prophase, metaphase, anaphase and telophase. Adefining feature of meiosis during prophase I sees homologous chromosomes (one maternal and one paternal) 'cross-over' by forming double strand breaks that recombine to exchange genetic information. Crossing over requires a special cellular scaffold called the synaptonemal complex (SC) that forms along each sister chromatid, binding them together (termed synapsis) to facilitate the genetic exchange.

Because the SC is unique to meiosis, the proteins that comprise this structure are useful in recognizing meiotic onset; particularly, synaptonemal complex protein 3 (SYCP3) and 1 (SYCP1) which form part of the lateral element of the SC (extending along the length of the chromosome) and the central element, respectively (Dobson et al., 1994; Heyting et al., 1988; Klink et al., 1997). Other markers include factors involved in double strand break formation and repair: SPOII (Spo11 meiotic protein covalently bound to DSB homolog [S. cerevisiae]), $\gamma \mathrm{H} 2 \mathrm{AX}$ (H2A histone family, member $\mathrm{X}$ ), Rad51 (Rad51 homolog [S. cerevisiae]) and DMC1 (dosage suppressor of mck1 homolog, meiosis-specific homologous recombination) (Keeney et al., 1997; Pittman et al., 1998; Yoshida et al., 1998). These proteins, in addition to chromosome structure/morphology, are considered reliable hallmarks of meiotic entry, while gene expression of Sycp3 is considered a marker of germ cells preparing for meiosis, rather than robust meiotic entry (Novak et al., 2006).

\section{Entry into meiosis: a role for retinoic acid}

For many years it was unclear whether germ cells were intrinsically programmed to enter meiosis, or if they were responding to signals from the somatic cell environment. Evidence for cellautonomous meiosis entry was seen in several experimental situations: when germ cells migrated to ectopic locations, such as the adrenal gland or mesonephros, though they were devoid of the testicular or ovarian niche, some germ cells were observed entering meiosis (McLaren 1983; Upadhyay and Zamboni 1982; Zamboni and Upadhyay 1983). Similarly, when germ cells were co-cultured with other tissues such as embryonic lung cells, meiosis entry was also witnessed (McLaren and Southee 1997). These findings suggested that meiosis entry was intrinsic to the developing germ cells rather than a result of somatic cue(s) (Donovan et al., 1986).

In contrast to this body of work, under a different set of experimental conditions it became clear that germ cells were being directed to enter meiosis by some exogenous factor. Co-culture of testis and ovary tissue revealed the ability of ovarian somatic cells to induce meiosis in XY germ cells (Byskov and Saxen 1976). Further, it was discovered that the mesonephros, and specifically the tubule network that makes up the rete ovarii/testis, was a source of meiosis-inducing signal(s) since, in its absence, meiosis was avoided (Byskov 1974; Byskov and Saxen 1976). Decades later, we now know that the factor produced from the mesonephros is retinoic acid (RA); RA is also produced in many extra-gonadal tissues (including the lung and adrenal), presumably explaining why ectopic germ cells enter meiosis in these locations. We now look at retinoid signaling in detail, discuss how it is implicated in germ cell development and ask the question: is RA necessary for meiosis?

\section{Fine-tuning retinoid levels: synthesis vs. degradation}

Retinoic acid, derived from retinol (vitamin A), is a lipophilic molecule synthesized within numerous tissues. There are two steps in RAsynthesis: firstly, retinol is reversibly converted to retinal by the alcohol dehydrogenase and short chain dehydrogenase/reductase family of enzymes. Secondly, in the presence of retinal dehydrogenase (RALDH) enzymes, retinal is oxidized irreversibly to RA.

RA is the active metabolite of retinoid signalling and a ligand for nuclear receptors that control gene transcription. Retinoic acid receptors (RARs) form heterodimers with retinoid-X receptors (RXRs); in the absence of RA the RAR/RXR complex is bound to retinoic acid response elements (RAREs) found in gene promoters 
and co-repressor recruitment induces transcriptional repression. Co-repressor complexes often comprise nuclear receptor corepressor (NCOR2) and histone deacetylases (HDACs). Binding of RA to the RAR/RXR complex alters the RAR ligand-binding domain such that co-activators, including nuclear receptor coactivator (NCOA), CREB binding protein (CBP) and p300, are recruited and transcription is promoted (reviewed by (Niederreither and Dolle 2008)). More that 500 genes have been identified as being RA-responsive, though it is likely that the majority of these are secondary targets (Balmer and Blomhoff 2002).

$\mathrm{RA}$ is able to be catabolised by the cytochrome P450 family of enzymes that convert RA to primary metabolites including 4-oxo$\mathrm{RA}, 4-\mathrm{OH}-\mathrm{RA}$ and 18-OH-RA. Within the P450 family there are three CYP26 isoforms: CYP26A1, B1 and C1, which share only 42-51\% aa sequence homology (Taimi et al., 2004; White et al., 2000a). The preferred substrate for CYP26A1 and B1 is all-transRA, while CYP26C1 favours 9-cis-RA. CYP26A1 has the highest catalytic activity and CYP26B1 the highest affinity for all-trans-RA, respectively (Topletz et al., 2012). There are conflicting reports as to whether the metabolites produced during RA oxidation are biologically active; in vitro several oxidative metabolites have been shown capable of binding RARs and possess pharmacological activity (Idres et al., 2002). Further, differentiation and proliferation was stimulated by some metabolites in spermatogonia in vitamin A-deficient mice (Gaemers et al., 1996) and in epithelial differentiation of intestinal cells in vivo (McCormick et al., 1978). In contrast to these adult tissues described above, it seems that RA oxidative metabolites are superfluous to mouse embryonic development; genetic ablation of the gene encoding the RA-producing enzyme RALDH2 rescued the affects of Cyp26a1 loss of function in mice (Niederreither et al., 2002).

The amount of RA to which a particular cell or tissue is exposed is tightly regulated, being controlled at multiple levels (reviewed by (Niederreither and Dolle 2008; Pennimpede et al., 2010)). First, the availability of retinol during embryonic development is dependent on the mother's diet. Secondly, RA-producing enzymes convert retinol to all-trans-RA at different efficiencies; therefore, RA concentration is determined by which retinal dehydrogenase enzyme (RALDH1, 2 or 3) a particular tissue expresses. Thirdly, RA-degrading enzymes degrade RA to polar metabolites with different efficiencies; therefore, RAconcentration is affected by which degradation enzyme (CYP26A1, B1, C1) the tissue expresses. Fourthly, the nuclear receptors for RA (RARs $\alpha, \beta, \gamma ; \mathrm{RXRs}$ ) each have different responsiveness for both RAand their co-factors (both repressors and activators); this determines a cell's sensitivity in the presence and absence of RA. Additionally, each RAR displays tissue-specific expression, allowing for further fine-tuning of the intracellular response to RA.

\section{Is retinoic acid necessary for meiosis?}

Even before the RA metabolism pathway was elucidated in the 1960s (Dowling and Wald 1960), vitamin A deficiency (VAD) in rats had highlighted the importance of this essential nutrient for both male and female reproduction (Evans 1928; Wolbach and Howe 1925). It was later discovered that dietary supplementation of VAD rats with either vitamin A or RA overcame the block in meiosis and restored male fertility (Morales and Griswold 1987; Van Pelt and De Rooij 1990). Studies of female VAD rats determined that 40
- $230 \mathrm{mcg} / \mathrm{rat} / \mathrm{day}$ of RA was required for ovulation, fertilisation, implantation and subsequent embryo development: the higher doses needed from mid-gestation onwards (Kaiser et al., 2003; See et al., 2008; White et al., 2000b; White et al., 1998). Such studies have uncovered the important roles for RA during many aspects of development, reviewed by (Clagett-Dame and Knutson 2011).

With respect to fetal germ cell development, RAwas first reported in this system as a pro-survival and proliferation factor for in vitro culture of germ cells at 8.5, 11.5 and 13.5 (Koshimizu et al., 1995; Morita and Tilly 1999) and female germ cells were found to express RARs at 13.5 dpc (Morita and Tilly 1999). In rat ovaries, RA and an RAR $\alpha$ agonist were found to accelerate germ cell progression through meiosis (Livera et al., 2000). Later, expression screens of whole embryonic gonads highlighted male-specific expression of the RA-degradation enzyme Cyp26b1 (Bowles et al., 2006; Menke and Page 2002) and female-specific expression of the RAresponsive gene Stra8 (Bowles et al., 2006; Menke et al., 2003). These observations provided the first hints that RA levels might be providing instructive cues for female germ cells.

Stimulated by retinoic acid, gene 8 (Stra8), as its name implies, was first identified as an immediate early RA-responsive gene from P19 embryonal carcinoma (EC) cells: RA induces Stra8 expression in these cells in as little as 2 hours (Bouillet et al., 1995; OuladAbdelghani et al., 1996). Two putative RAREs have been identified within the Stra8 promoter and, using mutational analysis, both appear to be required for RA-induced expression in F9 cells (Wang and Tilly 2010). While the structure and precise function of STRA8 remains a mystery, its expression is restricted to pre-meiotic germ cells (during oogenesis and spermatogenesis) and, upon stimulation with RA, embryonic stem (ES) cells and EC cell lines P19 and F9 (Bouillet et al., 1995; Oulad-Abdelghani et al., 1996). Importantly, using genetic deletion in mice, Stra8 was shown to be essential for germ cell initiation of meiosis in both sexes (Anderson et al., 2008; Baltus et al., 2006); in its absence germ cells fail to undergo pre-meiotic DNA replication and subsequent meiotic chromosome condensation, cohesion, synapsis and recombination.

As mentioned, expression of Stra8in female germ cells, together with expression of Cyp26b1 in the testis, suggested a mechanism for meiosis regulation in the developing gonads: RA was present in the fetal ovary to induce Stra8 (and initiate meiosis) and this signal would be actively degraded in the testis (to avoid meiosis) (Fig. 1). This notion has subsequently been tested in many ex vivo culture experiments as well as genetic models. Treatment of fetal testes or isolated $X Y$ germ cells with exogenous RA, RAR agonists (BMS-194753, BMS-213309, BMS-270394) or CYP26B1 inhibitors (ketoconazole, R115866) induced expression of many pre-meiotic and meiotic markers in XYgerm cells including Stra8, Sycp3, Dmc1 and $\gamma \mathrm{H} 2 \mathrm{AX}$ (Bowles etal., 2010; Bowles et al., 2006; Koubova et al., 2006; MacLean et al., 2007; Naillat et al., 2010; Trautmann et al., 2008). Importantly, in explant cultures, pharmacological inhibition of both CYP26B1 (to increase RA levels) and RARs (BMS204493, AGN193109; to prevent cells from responding to RA) caused no increase in Stra8 expression (Koubova et al., 2006) implying that CYP26b1 must function to degrade RA in this system. Conversely, in XX gonads, addition of RAR antagonists suppressed expression Stra8 relative to wild type controls (Bowles et al., 2006; Koubova et al., 2006), as did RALDH inhibition in both mouse and human ovaries using citral (Bowles et al., 2006; Le Bouffant et al., 2010).

In vivo models in which the RA signaling cascade is disrupted at 
different levels have also shed light on the role of retinoid signaling in germ cell meiosis. Loss of Cyp26b1 in mice led to a 3-fold increase in RAlevels within fetal testes; subsequently XY germ cells expressed markers of meiosis (Stra8, Scp3, Spoll, Dmc1, $\gamma \mathrm{H} 2 \mathrm{AX}$ ) and some progressed through to pachytene of meiosis I by $16.5 \mathrm{dpc}$ (Bowles et al., 2010; Bowles et al., 2006; MacLean et al., 2007). Interestingly, XX germ cells in Cyp26b1-/- ovaries also expressed higher levels of Stra8 relative to wildtype germ cells (Bowles et al., 2010). This finding is likely explained by the observation that, before its upregulation in testes at $12.5 \mathrm{dpc}$, Cyp26b1 is expressed at low levels in both $\mathrm{XX}$ and $\mathrm{XY}$ gonads at $11.5 \mathrm{dpc}$. Cyp26b1 expression at this time would presumably ensure that germ cells arriving at the genital ridges are not exposed to RA immediately. In the Cyp26b1 knockout, exposure to RA at this early stage was found to induce premature meiotic entry (Bowles et al., 2010).

While experiments involving the Cyp26bknockout mouse model confirmed that $X Y$ germ cells are capable of responding to RA (just like $X X$ germ cells) in this artificial situation, more direct evidence for RA's instructive role during natural XX germ cell meiosis came
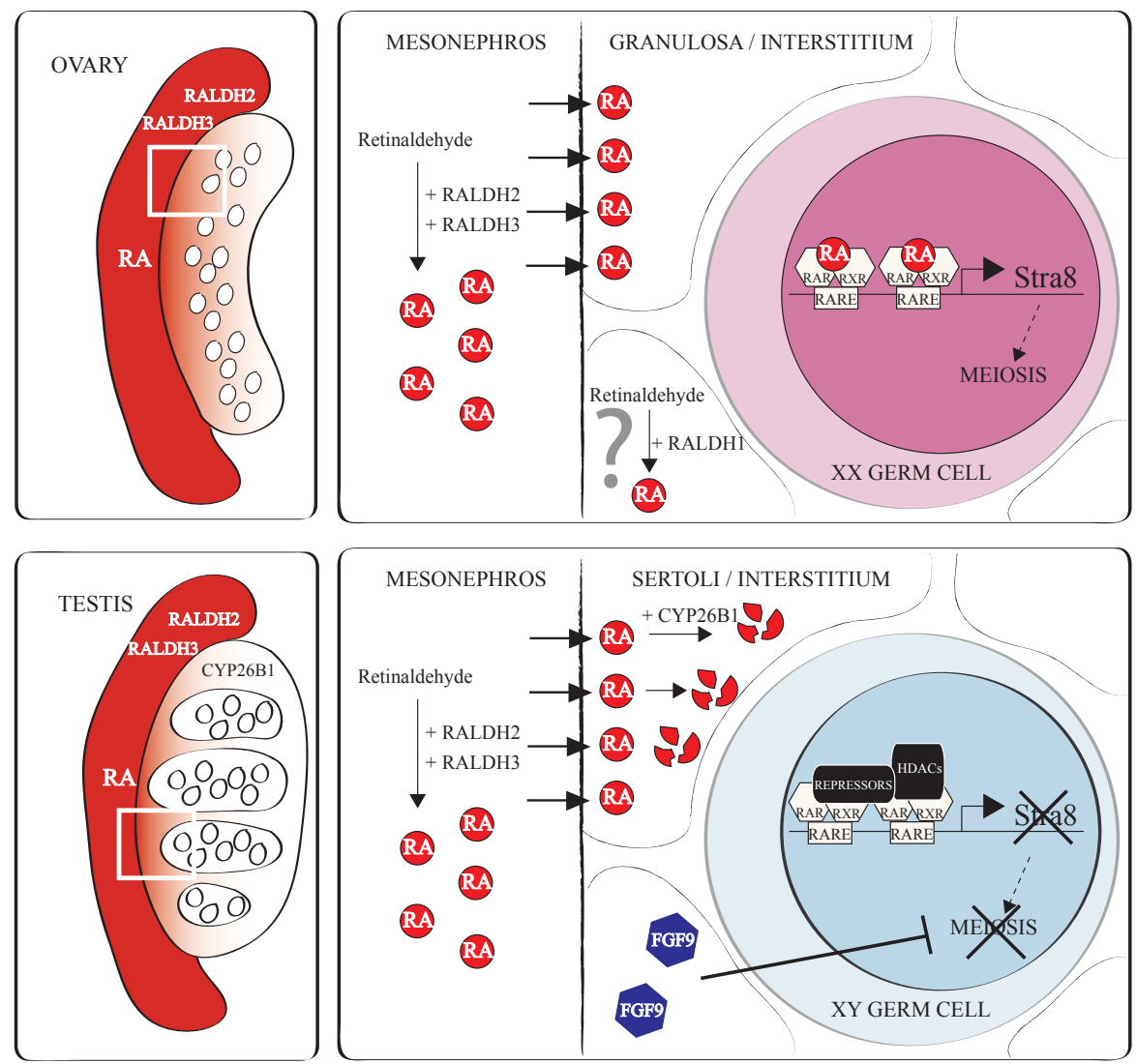

Fig. 1. Regulation of germ cell meiosis by retinoic acid. The mesonephros attached to the ovary or the testis expresses the retinoic acid (RA) synthesizing enzymes RALDH2 and RALDH3, resulting in the production of high levels of $R A$. RA produced in the mesonephros diffuses into the ovary where it acts directly on germ cells. RA binds RAR/RXRs on both identified RAREs of the Stra8 promoter to induce transcription. Meiosis then progresses in ovarian germ cells. The granulosa and interstitial cells express RALDH1 at low levels, perhaps also contributing to the local production of RA within the ovary. In the testis, Sertoli and interstitial cells express the RAdegrading enzyme CYP26B1, preventing RA from stimulating Stra8 transcription and subsequent meiosis in testicular germ cells. In the absence of RA, repressor co-factors including HDACs bind the RAREs of the Stra8 promoter to repress transcription. Additionally, FGF9 produced by the Sertoli cells acts directly on testicular germ cells to inhibit meiosis. from analysis of VAD ovarian development. In rat embryos severely ficient for vitamin A (mothers fed just 1.5 $\mathrm{ug}$ all-trans RA per gram press Stra8or enter meiosis (Li and Clagett-Dame 2009). heffect was dose-dependent: numbers of meiotic germ cells were ( Clagett-Dame 2009). In that study, germ cell numbers remained unchanged between VAD and control ovaries, demonstrating that dietary intake of Vitamin A positively correlates with meiosis entry in $\mathrm{XX}$ fetal germ cells in rodents.

Notably, induction of meiosis by RA does not appear to be limited to fetal rodent ovarian development. Recently, expression A synthesising enzymes (RALDH1, 2 and 3), along with RAR 2011; Le Bouffant et al., 2010). Using a human fetal organ culture system, RALDH1 was found to be expressed at highest levels during meiosis initiation and its inhibition using citral reduced numbers of meiotic germ cells. Conversely, addition of exogenous RA to this system increased numbers of meiotic germ cells relative to controls (Childs et al., 2011). RA metabolism has also been studied in chickens: here RALDH2 appears the predominant RA synthesising enzyme that triggers expression of Stra8 prior to meiotic entry (Nekrasova et al., 2011; Smith et al., 2008; Yu et al., 2012). Ovarian and testicular cultures of an amphibian species, Pleurodeles waltl, with RA have also highlighted a conserved role for RAdependent meiosis in vertebrates (Wallacides et al., 2009).

Unlike the situation in the developing ovary, testicular germ cells initiate meiosis just prior to puberty, which in rodents occurs within 1-2 weeks postnatally. In VAD mice modulation of RA signaling, both by the germ cells and supporting Sertoli cells, was shown to be responsible for the synchronous cycling of germ cell differentiation (Sugimoto et al., 2012). Data on whether human testes, or testes in other vertebrates, similarly utilise RA regulation for this purpose is currently lacking, reviewed by (Hogarth et al., 2011).

\section{Where does the retinoic acid come from?}

While the initial clue that RA was involved in germ cell meiosis was ovarian expression of Stra8 and testicular expression of Cyp2b1, a more complete picture of which cells in the developing gonads respond to RA and how, when, and where it is degraded has now been formed. But what is the source of the RA? As mentioned, very early work revealed that the mesonephros was required for inducing meiosis in XX germ cells (Byskov 1974; Byskov and Saxen 1976); this ability was evidently not restricted to the XX mesonephros, since mesonephroi from both sexes could equally induce meiosis 
in XY germ cells (Byskov and Saxen 1976; O and Baker 1976). It was not surprising, then, to find that Raldh2 is expressed at high levels in the mesonephric duct and tubules, which are physically connected to the anterior end of the gonads of both sexes (Bowles et al., 2006; Byskov 1974). Raldh3 has also been detected in the mesonephros at $10.5 \mathrm{dpc}$ (Zhao et al., 2009). Using two transgenic assays in which LacZ expression is driven by the RAR $\beta$ promoter to provide a read-out for RA production, F9 RARE reporter cells (Wagner et al., 1992) and the RARE-lacZ mouse line (Rossant et al., 1991), mesonephric cells triggered a strong $\beta$-galactosidase response in both models indicating high levels of RA were being produced from this tissue (Bowles et al., 2006). Therefore it was hypothesized that the mesonephros is the source of RA, which flows into the adjacent gonad in both sexes to induce meiosis in $\mathrm{XX}$ germ cells but is degraded in the Cyp26b1-expressing testis (Bowles et al., 2006)(Fig. 1). A recent study of $11.5 \mathrm{dpc}$ ovaries cultured without the mesonephros observed some XX germ cells entering meiosis, although the presence of the mesonephros and/ or RA sped up meiotic progression (Guerquin et al., 2010). This is somewhat surprising in view of recent independent studies that confirmed the necessity of the mesonephros (Kumar et al., 2011); perhaps differing culture conditions, including media/sera, and timing of these assays account for the discrepancies. Additionally, because the ovary itself expresses Raldh1 (Bowles et al., 2009), albeit at low levels, it is possible that there was sufficient RA present in this culture system to allow some germ cells to enter meiosis. RALDH1 is known to be much less efficient in generating all-trans RA and has been identified at sites where low levels of RA are required for morphogenesis (Haselbeck et al., 1999). As depicted in Fig. 1, RALDH1 expression in the ovary could provide another source of RA under normal conditions, as appears to be the case in the human ovary (Childs et al., 2011).

\section{How much retinoic acid?}

The local concentration of RA has not been measured for the gonad or mesonephros, but concentrations at other sites in 13.5 dpc mouse embryos are reported to be between 10-40nM (Horton and Maden 1995). While exogenous RA was initially implicated in germ cell meiosis in organ culture using much higher concentrations (0.7-1 $\mu \mathrm{M}$; (Bowles et al., 2006; Koubova et al., 2006), more recent studies have demonstrated that much lower levels (as low as 1nM) are sufficient for not only activation of Stra8 but also functional meiosis (Bowles et al., 2010; Chen et al., 2012; Ohta et al., 2010; Zhou et al., 2008). Further, in vitro, high levels of RAare detrimental to germ cell survival in both testes and ovaries (Best and Adams 2009). Therefore, it is likely that a very low levels of endogenous RA are sufficient to induce meiosis in the in vivo situation.

\section{Challenging the retinoic acid theory}

Recently, a study by Kumar et al., 2011 investigating meiotic induction in the absence Raldh2 and Raldh3 has challenged the theory that meiotic induction is dependent on RA. Three conclusions are drawn from that study: Firstly, in the absence of RAproducing enzymes RALDH2 and RALDH3, Stra8 was found to be expressed in fetal ovaries at $13.5 \mathrm{dpc}$, leading the authors to conclude that RA is unnecessary for meiotic induction. Secondly, Stra8 expression was observed in fetal testes when CYP26b1 was chemically inhibited with ketoconazole, but only in the presence of the mesonephros, leading the authors to propose the existence of a CYP26B1-sensitive factor produced by the mesonephros, that is not RA, is necessary for meiotic induction. Thirdly, using ChIP, the putative RARE elements of the Stra8 promoter were found to be bound by RAR antibodies only weakly, leading to the conclusion that Stra8 is unlikely to be regulated by RA in vivo. Given the persuasive evidence pointing to a finely tuned mechanism of RA signaling controlling germ cell meiosis, the findings of Kumar et al., 2011 are surprising. However, alternative explanations for the conclusions of that study are presented below (also thoroughly reviewed by (Griswold et al., 2012)).

Analyzing Raldh2-/-;Raldh3-/- double-mutant embryos, no RA activity was detectable in the gonad or mesonephros using the RARE-LacZ reporter line, which the authors show to be sensitive to 25nM RA and above (Kumar et al., 2011). As mentioned already, germ cells respond by up-regulating Stra8 in the presence of very low levels of RA in vitro (as little as 1nM; (Bowles et al., 2010; Chen et al., 2012; Ohta et al., 2010; Zhou et al., 2008)). Additionally, redundancy within the RALDH family has been reported in tissues such as the dorsal retina (Fan et al., 2003) and it is possible that RALDH1 expressed in the ovary produces sufficient levels of RA in the absence of RALDH2 and RALDH3 to induce meiosis even if not sufficiently high to elicit RARE-LacZ reporter expression. Therefore, biochemical quantification of RA levels in the Raldh2/-;Raldh3-/- mutants should be sought before excluding a role for $\mathrm{RA}$ in meiosis induction.

Using ChIP analysis in gonadal tissue, the two putative RARE sites in the Stra8 promoter showed only weak binding to RAR antibodies (Kumar et al., 2011), leading the authors to suggest that RA does not bind to and stimulate Stra8 expression in vivo. The extremely low contribution of Stra8-expressing germ cells in this assay however, has undoubtedly biased this result to reflect the situation in somatic cells of the gonad. We suggest that the weak binding of RAR $\beta$ to the most proximal RARE (Kumar et al., 2011) may instead be a very significant positive result, given the low germ cell: somatic cell ratio at $13.5 \mathrm{dpc}$.

Finally, RA is the only known substrate of CYP26B1, making the suggestion of a mesonephros-derived, non-RA, CYP26B1degraded factor responsible for inducing meiosis untenable at present.

\section{Meiotic competence: what makes germ cells so special?}

Although RA directs differentiation and patterning in many embryonic tissues, only the germ cell lineage responds to this morphogen by entering meiosis. What is it that makes germ cells respond to RA in this unique way? A major clue comes from the epigenetic state of germ cells residing in the genital ridges.

Unlike the rest of the somatic cells in the developing embryo, germ cells undergo genome-wide de-methylation (Hajkova et al., 2002; Sato et al., 2003; Szabo et al., 2002). Methylated promoter regions are generally associated with gene silencing and hypomethylated regions with gene transcription; $D d x 4$, Dazl, Gcna1 and Scp3 are common germ cell genes that become hypomethylated, and therefore expressed, upon entry into the gonad (Maatouk et al., 2006). Hypomethylation largely occurs by $12.5 \mathrm{dpc}$ for most genes investigated (Guibert et al., 2012; Hajkova et al., 2002; Henckel et al., 2012; Szabo et al., 2002; Szabo and Mann 1995) and female 
germ cells display less global methylation than male germ cells at $13.5 \mathrm{dpc}$ (Popp et al., 2010). Sex-specific re-methylation is acquired during late gestation and perinatally for male and female germ cells, respectively (Davis et al., 2000; Li et al., 2004; Ueda et al., 2000). In addition to global de-methylation, germ cells also lose repressive histone modifications, including H3K27me3 and H3K9me3, and are positive for the active histone modification H3K9ac (Abe et al., 2011; Hajkova et al., 2008; Seki et al., 2005). These marks indicate weak histone-DNAinteraction and, together with global DNA hypomethylation and chromosome decondensation (Hajkova et al., 2008), germ cell chromatin is considered to be in an 'open' state. Undoubtedly, this chromatin configuration would have a bearing on the suite of genes that respond to RA exposure; however there have been few studies that test this hypothesis directly.

One factor potentially linking chromatin organization with RAresponsiveness is chromobox homologue 2 (CBX2). CBX2 is a polycomb group protein involved in chromatin remodelling and defines the RA-sensitive window for Hox gene expression during early embryogenesis (Bel-Vialar et al., 2000). XY germ cells devoid of $C b x 2$ exhibit premature meiosis suggesting that the chromatin restructuring by CBX2 is necessary to avoid RA stimulation of meiosis in these cells (Baumann and De La Fuente 2011).

As mentioned, HDACs are among many co-factors with which RARs associate to negatively regulate transcription (Hong et al., 1997). In pre-meiotic germ cells, HDACs have been shown by co-immunoprecipitation to directly interact with RAR $\gamma$ (Wang and Tilly 2010). When histone acetylation (repression) was artificially abolished using the HDAC inhibitors trichostatin-A (TSA) and suberoylanilide hydroxamic acid (SAHA), the meiotic markers STRA8 and SYCP3 were detected in a few XY germ cells, as was the case when they were treated with RA (Wang and Tilly 2010). In F9 pre-meiotic cells, HDAC inhibition with TSA amplified RA-induced Stra8 promoter activation. Using mutation analysis, a region about 920bp upstream of the Stra8 transcription start site was required for the HDAC-mediated repression in vitro (Wang and Tilly 2010). Whether such a mechanism is relevant to in vivo germ cell development remains to be determined: as mentioned previously, pre-meiotic germ cells already possess 'open' and accessible chromatin.

\section{Conclusions}

Although vitamin A deficiency was associated with infertility several decades ago (Dowling and Wald 1960), it is only recently that we have begun to unravel how RA metabolism directs meiosis during fetal ovarian development and postnatal testis development. A complex picture of RA metabolism and catabolism is emerging: RA is synthesised in the mesonephros of both sexes but is catabolised in the developing mouse testis to prevent germ cells from responding to the morphogen. In the fetal mouse ovary, RA induces Stra8 expression in germ cells and they subsequently enter meiosis. This paradigm appears to hold true for multiple species, including human, chicken and amphibian.

But can we conclude that RA is necessary and sufficient for meiotic entry? Certainly, when RA levels are reduced through insufficient dietary intake of vitamin A, meiosis is compromised in a dose-dependent fashion. Similar effects are observed in vitro when RA synthesis is antagonised, indicating that RA is necessary for correct entry into meiosis for XX germ cells. Exogenous addition of RA, either chemically or genetically, induces XY germ cells to aberrantly enter meiosis, confirming that RA is sufficient for meiotic entry. Given the importance of correctly differentiating the germ cell lineage for fertility, it is unlikely that RA alone would regulate the process of meiotic entry. Indeed, we now know that, in addition to degrading RA with expression of CYP26B1, the fetal testis re-enforces the male differentiation pathway by expressing fibroblast growth factor 9 (FGF9), which is inhibitory to meiosis induction in XY germ cells (Barrios et al., 2010; Bowles et al., 2010). Future studies will likely uncover additional regulators of meiosis (both positive and negative) in this system, where germ cell fate cannot be left to chance.

\section{References}

ABE, M., TSAI, S.Y., JIN, S.G., PFEIFER, G.P. and SZABO, P.E. (2011). Sex-specific dynamics of global chromatin changes in fetal mouse germ cells. PLoS One 6: e23848.

ANDERSON, E.L., BALTUS, A.E., ROEPERS-GAJADIEN, H.L., HASSOLD, T.J., DE ROOIJ, D.G., VAN PELT, A.M. and PAGE, D.C. (2008). Stra8 and its inducer, retinoic acid, regulate meiotic initiation in both spermatogenesis and oogenesis in mice. Proc Natl Acad Sci USA 105: 14976-14980.

ANDERSON, R., COPELAND, T.K., SCHOLER, H., HEASMAN, J. and WYLIE, C. (2000). The onset of germ cell migration in the mouse embryo. Mech Dev91:61-68.

BAILLIE, A.H. (1964). The Histochemistry and Ultrastructure of the Genocyte. J Anat 98: 641-645.

BALMER, J.E. and BLOMHOFF, R. (2002). Gene expression regulation by retinoic acid. J Lipid Res 43: 1773-1808.

BALTUS, A.E., MENKE, D.B., HU, Y.C., GOODHEART, M.L., CARPENTER, A.E., DE ROOIJ, D.G. and PAGE, D.C. (2006). In germ cells of mouse embryonic ovaries, the decision to enter meiosis precedes premeiotic DNA replication. Nat Genet 38: 1430-1434.

BARRIOS, F., FILIPPONI, D., PELLEGRINI, M., PARONETTO, M.P., DI SIENA, S., GEREMIA, R., ROSSI, P., DE FELICI, M., JANNINI, E.A. and DOLCI, S. (2010). Opposing effects of retinoic acid and FGF9 on Nanos2 expression and meiotic entry of mouse germ cells. J Cell Sci 123: 871-880.

BAUMANN, C. and DE LA FUENTE, R. (2011). Role of Polycomb Group Protein Cbx2/M33 in Meiosis Onset and Maintenance of Chromosome Stability in the Mammalian Germline. Genes (Basel) 2: 59-80.

BEL-VIALAR, S., CORE, N., TERRANOVA, R., GOUDOT, V., BONED, A. and DJABALI, M. (2000). Altered retinoic acid sensitivity and temporal expression of Hox genes in polycomb-M33-deficient mice. Dev Biol 224: 238-249.

BEST, D. and ADAMS, I.R. (2009). Sdmg1 is a component of secretory granules in mouse secretory exocrine tissues. Dev Dyn 238: 223-231.

BOUILLET, P., OULAD-ABDELGHANI, M., VICAIRE, S., GARNIER, J.M., SCHUHBAUR, B., DOLLE, P. and CHAMBON, P. (1995). Efficient cloning of cDNAs of retinoic acid-responsive genes in $\mathrm{P} 19$ embryonal carcinoma cells and characterization of a novel mouse gene, Stra1 (mouse LERK-2/Eplg2). Dev Biol 170: 420-433.

BOWLES, J., FENG, C.W., KNIGHT, D., SMITH, C.A., ROESZLER, K.N., BAGHERIFAM, S., HARLEY, V.R., SINCLAIR, A.H. and KOOPMAN, P. (2009). Male-specific expression of Aldh1a1 in mouse and chicken fetal testes: implications for retinoid balance in gonad development. Dev Dyn 238: 2073-2080.

BOWLES, J., FENG, C.W., SPILLER, C., DAVIDSON, T.L., JACKSON, A. and KOOPMAN, P. (2010). FGF9 suppresses meiosis and promotes male germ cell fate in mice. Dev Cell 19: 440-449.

BOWLES, J., KNIGHT, D., SMITH, C., WILHELM, D., RICHMAN, J., MAMIYA, S. YASHIRO, K., CHAWENGSAKSOPHAK, K., WILSON, M.J., ROSSANT, J. et al., (2006). Retinoid signaling determines germ cell fate in mice. Science 312:596-600.

BYSKOV, A.G. (1974). Does the rete ovarii act as a trigger for the onset of meiosis? Nature 252: 396-397.

BYSKOV, A.G. and SAXEN, L. (1976). Induction of meiosis in fetal mouse testis in vitro. Dev Biol 52: 193-200.

CHEN, W., JIA, W., WANG, K., ZHOU, Q., LENG, Y., DUAN, T. and KANG, J. (2012). Retinoic acid regulates germ cell differentiation in mouse embryonic stem cells 
through a Smad-dependent pathway. Biochem Biophys Res Commun418:571-577. CHILDS, A.J., COWAN, G., KINNELL, H.L., ANDERSON, R.A. and SAUNDERS, P.T. (2011). Retinoic Acid signalling and the control of meiotic entry in the human fetal gonad. PLoS One 6: e20249.

CLAGETT-DAME, M. and KNUTSON, D. (2011). Vitamin A in reproduction and development. Nutrients 3: 385-428.

DAVIS, T.L., YANG, G.J., MCCARREY, J.R. and BARTOLOMEI, M.S. (2000). The $\mathrm{H} 19$ methylation imprint is erased and re-established differentially on the parental alleles during male germ cell development. Hum Mol Genet 9: 2885-2894.

DOBSON, M.J., PEARLMAN, R.E., KARAISKAKIS, A., SPYROPOULOS, B. and MOENS, P.B. (1994). Synaptonemal complex proteins: occurrence, epitope mapping and chromosome disjunction. J Cell Sci 107 (Pt 10): 2749-2760.

DONOVAN, P.J., STOTT, D., CAIRNS, L.A., HEASMAN, J. and WYLIE, C.C. (1986). Migratory and postmigratory mouse primordial germ cells behave differently in culture. Cell 44: 831-838.

DOWLING, J.E. and WALD, G. (1960). The Biological Function of Vitamin a Acid. Proc Natl Acad Sci USA 46: 587-608.

EVANS, E.P., FORD, C.E. and LYON, M.F. (1977). Direct evidence of the capacity of the XY germ cell in the mouse to become an oocyte. Nature 267: 430-431.

EVANS, H.M. (1928). The effects of inadequate vitamin A on the sexual physiology of the female. J. Biol. Chem. 77: 651-654.

FAN, X., MOLOTKOV, A., MANABE, S., DONMOYER, C.M., DELTOUR, L., FOGLIO, M.H., CUENCA, A.E., BLANER, W.S., LIPTON, S.A. and DUESTER, G. (2003). Targeted disruption of Aldh1a1 (Raldh1) provides evidence for a complex mechanism of retinoic acid synthesis in the developing retina. Mol Cell Biol23: 4637-4648.

FORD, C.E., EVANS, E.P., BURTENSHAW, M.D., CLEGG, H.M., TUFFREY, M. and BARNES, R.D. (1975). A functional 'sex-reversed' oocyte in the mouse. Proc $R$ Soc Lond B Biol Sci 190: 187-197.

GAEMERS, I.C., VAN PELT, A.M., VAN DER SAAG, P.T. and DE ROOIJ, D.G. (1996). All-trans-4-oxo-retinoic acid: a potent inducer of in vivo proliferation of growtharrested A spermatogonia in the vitamin A-deficient mouse testis. Endocrinology 137: 479-485

GRISWOLD, M.D., HOGARTH, C.A., BOWLES, J. and KOOPMAN, P. (2012). Initiating meiosis: the case for retinoic acid. Biol Reprod 86: 35.

GUERQUIN, M.J., DUQUENNE, C., LAHAYE, J.B., TOURPIN, S., HABERT, R. and LIVERA, G. (2010). New testicular mechanisms involved in the prevention of fetal meiotic initiation in mice. Dev Biol 346: 320-330.

GUIBERT, S., FORNE, T. and WEBER, M. (2012). Global profiling of DNA methylation erasure in mouse primordial germ cells. Genome Res 22: 633-641.

HAJKOVA, P., ANCELIN, K., WALDMANN, T., LACOSTE, N., LANGE, U.C., CESARI, F., LEE, C., ALMOUZNI, G., SCHNEIDER, R. and SURANI, M.A. (2008). Chromatin dynamics during epigenetic reprogramming in the mouse germ line. Nature 452: 877-881.

HAJKOVA, P., ERHARDT, S., LANE, N., HAAF, T., EL-MAARRI, O., REIK, W., WALTER, J. and SURANI, M.A. (2002). Epigenetic reprogramming in mouse primordial germ cells. Mech Dev 117: 15-23.

HASELBECK, R.J., HOFFMANN, I. and DUESTER, G. (1999). Distinct functions for Aldh1 and Raldh2 in the control of ligand production for embryonic retinoid signaling pathways. Dev Genet 25: 353-364.

HAYASHI, K., DE SOUSA LOPES, S.M. and SURANI, M.A. (2007). Germ cell specification in mice. Science 316: 394-396.

HENCKEL, A., CHEBLI, K., KOTA, S.K., ARNAUD, P. and FEIL, R. (2012). Transcription and histone methylation changes correlate with imprint acquisition in male germ cells. EMBO J 31: 606-615.

HEYTING, C., DETTMERS, R.J., DIETRICH, A.J., REDEKER, E.J. and VINK, A.C. (1988). Two major components of synaptonemal complexes are specific for meiotic prophase nuclei. Chromosoma 96: 325-332.

HILSCHER, W. (1974). [Kinetics of prespermatogenesis and spermatogenesis]. Verh Anat Ges 68: 39-62.

HOGARTH, C.A., AMORY, J.K. and GRISWOLD, M.D. (2011). Inhibiting vitamin A metabolism as an approach to male contraception. Trends Endocrinol Metab 22: 136-144.

HONG, S.H., DAVID, G., WONG, C.W., DEJEAN, A. and PRIVALSKY, M.L. (1997) SMRT corepressor interacts with PLZF and with the PML-retinoic acid receptor alpha (RARalpha) and PLZF-RARalpha oncoproteins associated with acute promyelocytic leukemia. Proc Natl Acad Sci USA 94: 9028-9033.

HORTON, C. and MADEN, M. (1995). Endogenous distribution of retinoids during normal development and teratogenesis in the mouse embryo. Dev Dyn202:312-323.

IDRES, N., MARILL, J., FLEXOR, M.A. and CHABOT, G.G. (2002). Activation of retinoic acid receptor-dependent transcription by all-trans-retinoic acid metabolites and isomers. J Biol Chem 277: 31491-31498.

KAISER, M.E., MERRILL, R.A., STEIN, A.C., BREBURDA, E. and CLAGETT-DAME, M. (2003). Vitamin A deficiency in the late gastrula stage rat embryo results in a one to two vertebral anteriorization that extends throughout the axial skeleton. Dev Biol 257: 14-29.

KEENEY, S., GIROUX, C.N. and KLECKNER, N. (1997). Meiosis-specific DNA double-strand breaks are catalyzed by Spo11, a member of a widely conserved protein family. Cell 88: 375-384.

KLINK, A., LEE, M. and COOKE, H.J. (1997). The mouse synaptosomal complex protein gene Sycp3 maps to band C of chromosome 10. Mamm Genome 8: 376-377.

KOOPMAN, P., GUBBAY, J., VIVIAN, N., GOODFELLOW, P. and LOVELL-BADGE, R. (1991). Male development of chromosomally female mice transgenic for Sry. Nature 351: 117-121.

KOSHIMIZU, U., WATANABE, M. and NAKATSUJI, N. (1995). Retinoic acid is a potent growth activator of mouse primordial germ cells in vitro. Dev Biol 168: 683-685.

KOUBOVA, J., MENKE, D.B., ZHOU, Q., CAPEL, B., GRISWOLD, M.D. and PAGE, D.C. (2006). Retinoic acid regulates sex-specific timing of meiotic initiation in mice. Proc Natl Acad Sci USA 103: 2474-2479.

KUMAR, S., CHATZI, C., BRADE, T., CUNNINGHAM, T.J., ZHAO, X. and DUESTER, G. (2011). Sex-specific timing of meiotic initiation is regulated by Cyp26b1 independent of retinoic acid signalling. Nat Commun 2: 151.

LAWSON, K.A. (1999). Fate mapping the mouse embryo. Int J Dev Biol 43: 773-775.

LAWSON, K.A. and HAGE, W.J. (1994). Clonal analysis of the origin of primordial germ cells in the mouse. Ciba Found Symp 182: 68-84; discussion 84-91.

LE BOUFFANT, R., GUERQUIN, M.J., DUQUENNE, C., FRYDMAN, N., COFFIGNY, H., ROUILLER-FABRE, V., FRYDMAN, R., HABERT, R. and LIVERA, G. (2010). Meiosis initiation in the human ovary requires intrinsic retinoic acid synthesis. Hum Reprod 25: 2579-2590.

LI, H. and CLAGETT-DAME, M. (2009). Vitamin A deficiency blocks the initiation of meiosis of germ cells in the developing rat ovary in vivo. Biol Reprod 81: 996-1001.

LI, J.Y., LEES-MURDOCK, D.J., XU, G.L. and WALSH, C.P. (2004). Timing of establishment of paternal methylation imprints in the mouse. Genomics 84: 952-960.

LIU, C.F., LIU, C. and YAO, H.H. (2010). Building pathways for ovary organogenesis in the mouse embryo. Curr Top Dev Biol 90: 263-290.

LIVERA, G., ROUILLER-FABRE, V., VALLA, J. and HABERT, R. (2000). Effects of retinoids on the meiosis in the fetal rat ovary in culture. Mol Cell Endocrinol 165: 225-231

MAATOUK, D.M., KELLAM, L.D., MANN, M.R., LEI, H., LI, E., BARTOLOMEI, M.S. and RESNICK, J.L. (2006). DNA methylation is a primary mechanism for silencing postmigratory primordial germ cell genes in both germ cell and somatic cell lineages. Development 133: 3411-3418.

MACLEAN, G., LI, H., METZGER, D., CHAMBON, P. and PETKOVICH, M. (2007) Apoptotic extinction of germ cells in testes of Cyp26b1 knockout mice. Endocrinology 148: 4560-4567.

MCCORMICK, A.M., NAPOLI, J.L., SCHNOES, H.K. and DELUCA, H.F. (1978). Isolation and identification of 5, 6-epoxyretinoic acid: a biologically active metabolite of retinoic acid. Biochemistry 17: 4085-4090.

MCLAREN, A. (1983). Studies on mouse germ cells inside and outside the gonad. J Exp Zool 228: 167-171

MCLAREN, A. (1984). Meiosis and differentiation of mouse germ cells. Symp Soc Exp Biol 38: 7-23.

MCLAREN, A. and SOUTHEE, D. (1997). Entry of mouse embryonic germ cells into meiosis. Dev Biol 187: 107-113.

MENKE, D.B., KOUBOVA, J. and PAGE, D.C. (2003). Sexual differentiation of germ cells in XX mouse gonads occurs in an anterior-to-posterior wave. Dev Biol 262 303-312.

MENKE, D.B. and PAGE, D.C. (2002). Sexually dimorphic gene expression in the developing mouse gonad. Gene Expr Patterns 2: 359-367.

MOLYNEAUX, K.A., STALLOCK, J., SCHAIBLE, K. and WYLIE, C. (2001). Time-lapse 
analysis of living mouse germ cell migration. Dev Biol 240: 488-498.

MONK, M. and MCLAREN, A. (1981). X-chromosome activity in foetal germ cells of the mouse. J Embryol Exp Morphol 63: 75-84.

MORALES, C. and GRISWOLD, M.D. (1987). Retinol-induced stage synchronization in seminiferous tubules of the rat. Endocrinology 121: 432-434.

MORITA, Y. and TILLY, J.L. (1999). Segregation of retinoic acid effects on fetal ovarian germ cell mitosis versus apoptosis by requirement for new macromolecular synthesis. Endocrinology 140: 2696-2703.

NAILLAT, F., PRUNSKAITE-HYYRYLAINEN, R., PIETILA, I., SORMUNEN, R., JOKELA, T., SHAN, J. and VAINIO, S.J. (2010). Wnt4/5a signalling coordinates cell adhesion and entry into meiosis during presumptive ovarian follicle development. Hum Mol Genet 19: 1539-1550.

NEKRASOVA, A.A., LUKINA, N.A., KOZIKOVA, L.V. and SMIRNOV, A.F. (2011). [The effect of retinoic acid on the meiosis in the chick embryo (Gallus gallus domesticus)]. Tsitologiia 53: 659-664.

NIEDERREITHER, K., ABU-ABED, S., SCHUHBAUR, B., PETKOVICH, M., CHAMBON, P. and DOLLE, P. (2002). Genetic evidence that oxidative derivatives of retinoic acid are not involved in retinoid signaling during mouse development. Nat Genet 31: 84-88.

NIEDERREITHER, K. and DOLLE, P. (2008). Retinoic acid in development: towards an integrated view. Nat Rev Genet 9: 541-553.

NOVAK, I., LIGHTFOOT, D.A., WANG, H., ERIKSSON, A., MAHDY, E. and HOOG, C. (2006). Mouse embryonic stem cells form follicle-like ovarian structures but do not progress through meiosis. Stem Cells 24: 1931-1936.

O, W. and BAKER, T.G. (1976). Initiation and control of meiosis in hamster gonads in vitro. J Reprod Fertil 48: 399-401.

OHINATA, Y., PAYER, B., O'CARROLL, D., ANCELIN, K., ONO, Y., SANO, M., BARTON, S.C., OBUKHANYCH, T., NUSSENZWEIG, M., TARAKHOVSKY, A. et al., (2005). Blimp1 is a critical determinant of the germ cell lineage in mice. Nature 436: 207-213.

OHTA, K., LIN, Y., HOGG, N., YAMAMOTO, M. and YAMAZAKI, Y. (2010). Direct effects of retinoic acid on entry of fetal male germ cells into meiosis in mice. Biol Reprod 83: 1056-1063.

OULAD-ABDELGHANI, M., BOUILLET, P., DECIMO, D., GANSMULLER, A., HEYBERGER, S., DOLLE, P., BRONNER, S., LUTZ, Y. and CHAMBON, P. (1996). Characterization of a premeiotic germ cell-specific cytoplasmic protein encoded by Stra8, a novel retinoic acid-responsive gene. J Cell Biol 135: 469-477.

PALMER, S.J. and BURGOYNE, P.S. (1991). In situ analysis of fetal, prepuberal and adult $X X----X Y$ chimaeric mouse testes: Sertoli cells are predominantly, but not exclusively, XY. Development 112: 265-268.

PENNIMPEDE, T., CAMERON, D.A., MACLEAN, G.A., LI, H., ABU-ABED, S. and PETKOVICH, M. (2010). The role of CYP26 enzymes in defining appropriate retinoic acid exposure during embryogenesis. Birth Defects Res $\mathrm{A}$ Clin $\mathrm{Mol}$ Teratol 88: 883-894.

PITTMAN, D.L., COBB, J., SCHIMENTI, K.J., WILSON, L.A., COOPER, D.M., BRIGNULL, E., HANDEL, M.A. and SCHIMENTI, J.C. (1998). Meiotic prophase arrest with failure of chromosome synapsis in mice deficient for Dmc1, a germlinespecific RecA homolog. Mol Cell 1: 697-705.

POPP, C., DEAN, W., FENG, S., COKUS, S.J., ANDREWS, S., PELLEGRINI, M., JACOBSEN, S.E. and REIK, W. (2010). Genome-wide erasure of DNAmethylation in mouse primordial germ cells is affected by AID deficiency. Nature 463: 1101-1105.

RICHARDSON, B.E. and LEHMANN, R. (2010). Mechanisms guiding primordial germ cell migration: strategies from different organisms. Nat Rev Mol Cell Biol 11:37-49

ROSSANT, J., ZIRNGIBL, R., CADO, D., SHAGO, M. and GIGUERE, V. (1991). Expression of a retinoic acid response element-hsplacZ transgene defines specific domains of transcriptional activity during mouse embryogenesis. Genes Dev 5: 1333-1344.

SAITOU, M. (2009). Specification of the germ cell lineage in mice. Front Biosci 14: 1068-1087.

SAITOU, M., BARTON, S.C. and SURANI, M.A. (2002). A molecular programme for the specification of germ cell fate in mice. Nature 418: 293-300.

SATO, S., YOSHIMIZU, T., SATO, E. and MATSUI, Y. (2003). Erasure of methylation imprinting of Igf2r during mouse primordial germ-cell development. Mol Reprod Dev 65: 41-50.

SCHOLER, H.R., RUPPERT, S., SUZUKI, N., CHOWDHURY, K. and GRUSS, P. (1990).
New type of POU domain in germ line-specific protein Oct-4. Nature 344: 435-439.

SEE, A.W., KAISER, M.E., WHITE, J.C. and CLAGETT-DAME, M. (2008). A nutritional model of late embryonic vitamin A deficiency produces defects in organogenesis at a high penetrance and reveals new roles for the vitamin in skeletal development. Dev Biol 316: 171-190.

SEKI, Y., HAYASHI, K., ITOH, K., MIZUGAKI, M., SAITOU, M. and MATSUI, Y. (2005). Extensive and orderly reprogramming of genome-wide chromatin modifications associated with specification and early development of germ cells in mice. Dev Biol 278: 440-458.

SMITH, C.A., ROESZLER, K.N., BOWLES, J., KOOPMAN, P. and SINCLAIR, A.H. (2008). Onset of meiosis in the chicken embryo; evidence of a role for retinoic acid. BMC Dev Biol 8: 85.

SUGIMOTO, R., NABESHIMA, Y. and YOSHIDA, S. (2012). Retinoic acid metabolism links the periodical differentiation of germ cells with the cycle of Sertoli cells in mouse seminiferous epithelium. Mech Dev 128: 610-624.

SZABO, P.E., HUBNER, K., SCHOLER, H. and MANN, J.R. (2002). Allele-specific expression of imprinted genes in mouse migratory primordial germ cells. Mech Dev 115: 157-160.

SZABO, P.E. and MANN, J.R. (1995). Biallelic expression of imprinted genes in the mouse germ line: implications for erasure, establishment, and mechanisms of genomic imprinting. Genes Dev 9: 1857-1868.

TAIMI, M., HELVIG, C., WISNIEWSKI, J., RAMSHAW, H., WHITE, J., AMAD, M., KORCZAK, B. and PETKOVICH, M. (2004). A novel human cytochrome P450, CYP26C1, involved in metabolism of 9-cis and all-trans isomers of retinoic acid. J Biol Chem 279: 77-85.

TAM, P.P., ZHOU, S.X. and TAN, S.S. (1994). X-chromosome activity of the mouse primordial germ cells revealed by the expression of an X-linked lacZ transgene. Development 120: 2925-2932.

TOPLETZ, A.R., THATCHER, J.E., ZELTER, A., LUTZ, J.D., TAY, S., NELSON W.L. and ISOHERRANEN, N. (2012). Comparison of the function and expression of CYP26A1 and CYP26B1, the two retinoic acid hydroxylases. Biochem Pharmacol 83: 149-163.

TRAUTMANN, E., GUERQUIN, M.J., DUQUENNE, C., LAHAYE, J.B., HABERT, R. and LIVERA, G. (2008). Retinoic acid prevents germ cell mitotic arrest in mouse fetal testes. Cell Cycle $7:$ 656-664.

UEDA, T., ABE, K., MIURA, A., YUZURIHA, M., ZUBAIR, M., NOGUCHI, M., NIWA K., KAWASE, Y., KONO, T., MATSUDA, Y. et al., (2000). The paternal methylation imprint of the mouse $\mathrm{H} 19$ locus is acquired in the gonocyte stage during foetal testis development. Genes Cells 5: 649-659.

UPADHYAY, S. and ZAMBONI, L. (1982). Ectopic germ cells: natural model for the study of germ cell sexual differentiation. Proc Natl Acad Sci USA 79: 6584-6588.

VAN PELT, A.M. and DE ROOIJ, D.G. (1990). The origin of the synchronization of the seminiferous epithelium in vitamin A-deficient rats after vitamin A replacement. Biol Reprod 42: 677-682

WAGNER, M., HAN, B. and JESSELL, T.M. (1992). Regional differences in retinoid release from embryonic neural tissue detected by an in vitro reporter assay. Development 116: 55-66.

WALLACIDES, A., CHESNEL, A., CHARDARD, D., FLAMENT, S. and DUMOND, $H$. (2009). Evidence for a conserved role of retinoic acid in urodele amphibian meiosis onset. Dev Dyn 238: 1389-1398.

WANG, N. and TILLY, J.L. (2010). Epigenetic status determines germ cell meiotic commitment in embryonic and postnatal mammalian gonads. Cell Cycle 9:339-349.

WHITE, J.A., RAMSHAW, H., TAIMI, M., STANGLE, W., ZHANG, A., EVERINGHAM S., CREIGHTON, S., TAM, S.P., JONES, G. and PETKOVICH, M. (2000a) Identification of the human cytochrome $\mathrm{P} 450, \mathrm{P} 450 \mathrm{RAI}-2$, which is predominantly expressed in the adult cerebellum and is responsible for all-trans-retinoic acid metabolism. Proc Natl Acad Sci USA 97: 6403-6408.

WHITE, J.C., HIGHLAND, M., KAISER, M. and CLAGETT-DAME, M. (2000b). Vitamin A deficiency results in the dose-dependent acquisition of anterior character and shortening of the caudal hindbrain of the rat embryo. Dev Biol 220: 263-284.

WHITE, J.C., SHANKAR, V.N., HIGHLAND, M., EPSTEIN, M.L., DELUCA, H.F and CLAGETT-DAME, M. (1998). Defects in embryonic hindbrain development and fetal resorption resulting from vitamin A deficiency in the rat are prevented by feeding pharmacological levels of all-trans-retinoic acid. Proc Natl Acad Sci USA 95: 13459-13464.

WOLBACH, S.B. and HOWE, P.R. (1925). Tissue Changes Following Deprivation of 
Fat-Soluble a Vitamin. J Exp Med 42: 753-777.

YABUTA, Y., KURIMOTO, K., OHINATA, Y., SEKI, Y. and SAITOU, M. (2006). Gene expression dynamics during germline specification in mice identified by quantitative single-cell gene expression profiling. Biol Reprod 75: 705-716.

YING, Y., LIU, X.M., MARBLE, A., LAWSON, K.A. and ZHAO, G.Q. (2000). Requirement of Bmp8b for the generation of primordial germ cells in the mouse. Mol Endocrinol 14: 1053-1063.

YING, Y. and ZHAO, G.Q. (2001). Cooperation of endoderm-derived BMP2 and extraembryonic ectoderm-derived BMP4 in primordial germ cell generation in the mouse. Dev Biol 232: 484-492.

YOSHIDA, K., KONDOH, G., MATSUDA, Y., HABU, T., NISHIMUNE, Y. and MORITA, T. (1998). The mouse RecA-like gene Dmc1 is required for homologous chromosome synapsis during meiosis. Mol Cell 1: 707-718.
YU, M., YU, P., LEGHARI, I.H., GE, C., MI, Y. and ZHANG, C. (2012). RALDH2, the enzyme for retinoic acid synthesis, mediates meiosis initiation in germ cells of the female embryonic chickens. Amino Acids 44: 405-412.

ZAMBONI, L. and UPADHYAY, S. (1983). Germ cell differentiation in mouse adrenal glands. J Exp Zool 228: 173-193.

ZHAO, X., SIRBU, I.O., MIC, F.A., MOLOTKOVA, N., MOLOTKOV, A., KUMAR, S. and DUESTER, G. (2009). Retinoic acid promotes limb induction through effects on body axis extension but is unnecessary for limb patterning. Curr Biol19: 1050-1057.

ZHOU, Q., LI, Y., NIE, R., FRIEL, P., MITCHELL, D., EVANOFF, R.M., POUCHNIK, D., BANASIK, B., MCCARREY, J.R., SMALL, C. et al., (2008). Expression of stimulated by retinoic acid gene 8 (Stra8) and maturation of murine gonocytes and spermatogonia induced by retinoic acid in vitro. Biol Reprod 78: 537-545.

\section{Further Related Reading, published previously in the Int. J. Dev. Biol.}

Impaired meiotic competence in putative primordial germ cells produced from mouse embryonic stem cells Marianna Tedesco, Donatella Farini and Massimo De Felici

Int. J. Dev. Biol. (2011) 55: 215-222

Differentiation of mouse primordial germ cells into female or male germ cells

N Nakatsuji and S Chuma

Int. J. Dev. Biol. (2001) 45: 541-548

The meiotic specific synaptonemal complex protein SCP3 is expressed by female and male primordial germ cells of the mouse embryo

A D Di Carlo, G Travia and M De Felici

Int. J. Dev. Biol. (2000) 44: 241-244

Interleukin-2 induces the proliferation of mouse primordial germ cells in vitro Cristina Eguizabal, Maria D. Boyano, Alejandro Díez-Torre, Ricardo Andrade, Noelia Andollo, Massimo De Felici and Juan Aréchaga

Int. J. Dev. Biol. (2007) 51: 731-738

Foetal germ cells: striking the balance between pluripotency and differentiation Patrick Western

Int. J. Dev. Biol. (2009) 53: 393-409

5 yr ISI Impact Factor $(2011)=2.959$

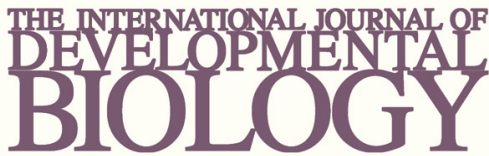

Volume 54 Nos. $6 / 7$
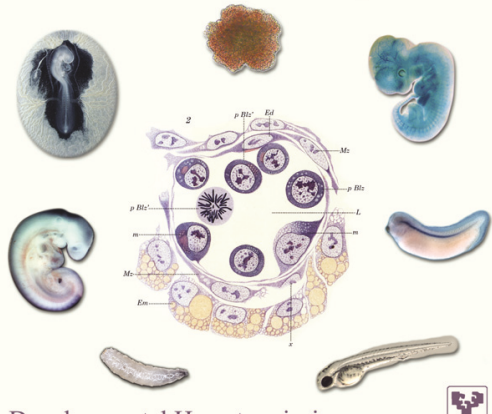

Developmental Hematopoiesis

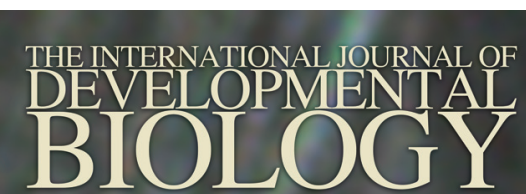

Special Issue

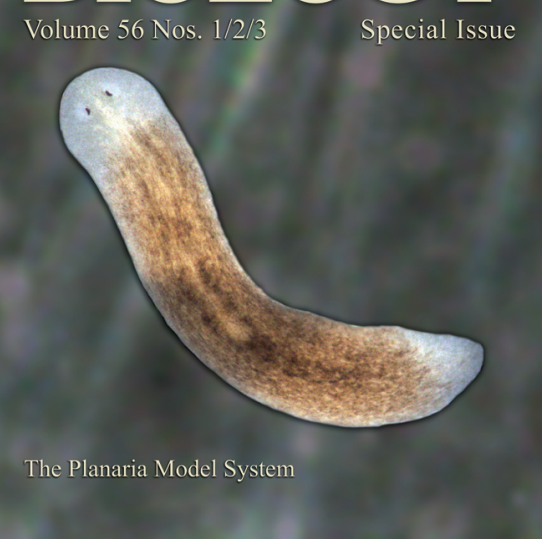

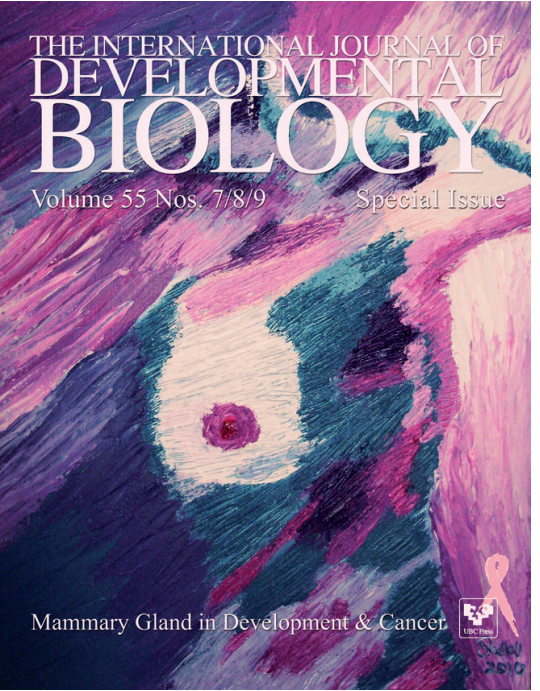
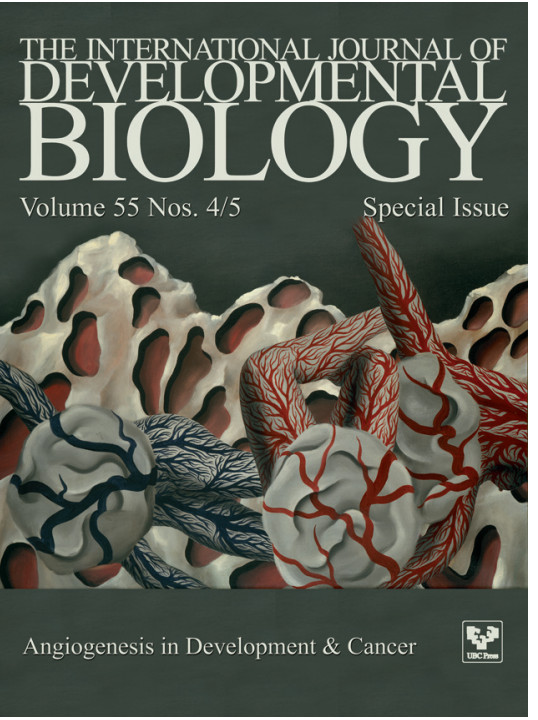